\title{
'Peacework': A Cucumber mosaic virus-resistant Early Red Bell Pepper for Organic Systems
}

\author{
Michael Mazourek, George Moriarty, Michael Glos, Maryann Fink, \\ and Mary Kreitinger \\ Cornell University, Department of Plant Breeding and Genetics, Ithaca, NY \\ 14853 \\ Elizabeth Henderson, Greg Palmer, and Ammie Chickering \\ Peacework Organic Farm, Newark, NY 14513
}

Danya L. Rumore, Deborah Kean, and James R. Myers
Oregon State University, Department of Horticulture, Corvallis, OR 97331

John F. Murphy

Department of Entomology and Plant Pathology, Auburn University, AL 36849

\section{Chad Kramer and Molly Jahn' \\ University of Wisconsin-Madison, College of Agricultural and Life Sciences, 140 Agricultural Hall, Madison, WI 53706}

Additional index words. Cucumber mosaic virus, CMV, organic, bell pepper, virus resistance, Capsicum

'Peacework' is a new open-pollinated, early red bell pepper cultivar with Cucumber mosaic virus (CMV) resistance developed for and within organic systems. Development of this cultivar was conducted at Cornell University's Department of Plant Breeding and Genetics in Ithaca, NY, and Freeville Organic Research Farm in Freeville, NY, as well as at the farms of members of the Organic Seed Partnership (OSP) and in cooperation with the Northeast Organic Farming Association of New York. 'Peacework' is well adapted to northeastern and northwestern U.S. growing conditions and also provides CMV resistance that could be transferred to peppers adapted to organic production in other environments. The performance and quality of 'Peacework' is comparable to 'King of the North', a cultivar popular for

Received for publication 12 Nov. 2008. Accepted for publication 13 Jan. 2009.

Funding was provided by California Pepper Commission, the Organic Farming Research Foundation (OFRF), California Pepper Improvement Foundation, and USDA-SARE (Award \#LNED4-204) (USDA-CSREES Award \#2004-51300-02229).

Brynda Beeman, Jason Cavatorta, and Nicholas Strutt were instrumental in conducting trials and provided breeding assistance. We gratefully acknowledge the support of a Howard Hughes Medical Institute Fellowship awarded to Danya Rumore to support her summer internship with the OSU Vegetable Breeding and Genetics Program. 'Peacework' was named for Peacework Organic Farm, Newark, NY, where much of the selection was performed.

${ }^{1}$ To whom reprint requests should be addressed; e-mailmjahn@cals.wisc.edu. organic production in the Northeast. The pedigree of 'Peacework' potentially combines several taxonomically distinct sources of CMV resistance and tolerance, which would increase the degree and durability of resistance to this economically important virus. 'Peacework' was evaluated for yield, size, earliness, and fruit wall thickness in organic replicated trials in Oregon in 2006 and in New York in 2007 and for flavor, productivity, and fruit quality by members of the OSP, who trialed 'Peacework' on their farms.

'Peacework' was developed to be a Cucumber mosaic virus-resistant pepper similar to 'King of the North', a bell pepper cultivar recognized as being popular among organic growers in the northeastern United States. Existing CMV-resistant bell lines developed at Cornell University were used as the source of resistance to introduce CMV resistance to 'King of the North'. To ensure the resistant cultivar would meet their needs and be an acceptable alternative to 'King of the North', a network of organic growers was organized to trial these varieties on their farms and participate in the final selections.

Cucumber mosaic virus is a widespread pathogen that infects more than 1200 plant species and is readily transmitted by more than 80 species of aphids (Palukaitis and Garcia-Arenal, 2003). The wide plant host range makes cucumber mosaic a disease that is particularly difficult to control; weeds may act as reservoirs for the virus and there are few options for rotation crops that would not perpetuate the virus in growers' fields (http:// vegetablemdonline.ppath.cornell.edu/). Fur- thermore, CMV can alter resistance responses to other viruses such as Pepper mottle virus when plants are coinfected with both viruses (Guerini and Murphy, 1999; Murphy and Kyle, 1995). Sources of resistance to CMV have been identified in pepper, but the inheritance of the trait is complex and the development of new resistant varieties is not straightforward (Ben Chaim et al., 2001; Greenleaf, 1986; Grube et al., 2000).

\section{Origin}

The Capsicum frutescens accession BG2814-6 (J. LaBorde, Mexico) and Capsicum annuum cultivar 'Perennial' (A. Palloix, INRA, France) are resistant to CMV (Grube et al., 2000). These two sources of resistance were combined in a cross between the resistant parents (Fig. 1). The hybrid was crossed with the bell cultivar 'Jupiter' [T. Williams, Syngenta (NK brand), Golden Valley, MN], which eliminated pungency and provided a large, blocky bell fruit type (Stewart et al., 2005). The CMV susceptibility in 'Jupiter' also provided a clear contrast to assess the transfer of resistance into a bell background. Plants were selected for CMV resistance at the $\mathrm{F}_{2}$ generation as judged by a lack of virus symptoms at 10 to $14 \mathrm{~d}$ after two manual inoculations with CMV-V27 as per established protocols (Grube et al., 2000). The V27 isolate produces severe symptoms that have made it useful in applied CMV resistance breeding programs at Cornell (Grube et al., 2000). Resistant $F_{2}$ plants were crossed to and selected in two cycles to 'Verdel' [Syngenta (Rogers brand), Boise, ID], a bell pepper with a genetic background with reduced symptom severity response to CMV (Thorup, 2000). The resulting progeny were further crossed to 'Gadir' (Clause Seeds, Portes lès Valence, France), a bell pepper with CMV resistance/tolerance derived from C. baccatum (Grube, 1999), and tested for $\mathrm{CMV}$ resistance in the $\mathrm{F}_{3}$ families of resistant $\mathrm{F}_{2}$ selections. These resistant $\mathrm{F}_{3}$ plants potentially comprise a CMV resistance package of four sources of resistance/tolerance from three species of pepper. Given the number of resistance alleles and their complex inheritance from these sources, it would be interesting to perform genomic analyses on the resistant selections to determine which genomic regions were transferred from the resistant parents. Given the number of crosses in the preceding portion of the pedigree and the following crosses and selections for quality and agronomic performance, it is unlikely that all of the resistance loci were retained.

Crosses were made with 'King of the North' to introduce CMV resistances and $\mathrm{F}_{2}$ individuals from this cross that lacked CMVinduced symptoms after inoculations were selected (Fig. 1). These selections were crossed with 'Early Red Sweet' (Frank Kutka, MN) to improve earliness for the shorter northern growing season. Asymptomatic plants were self-pollinated and inbred selections were shared with organic pepper growers participating in the Organic Seed 


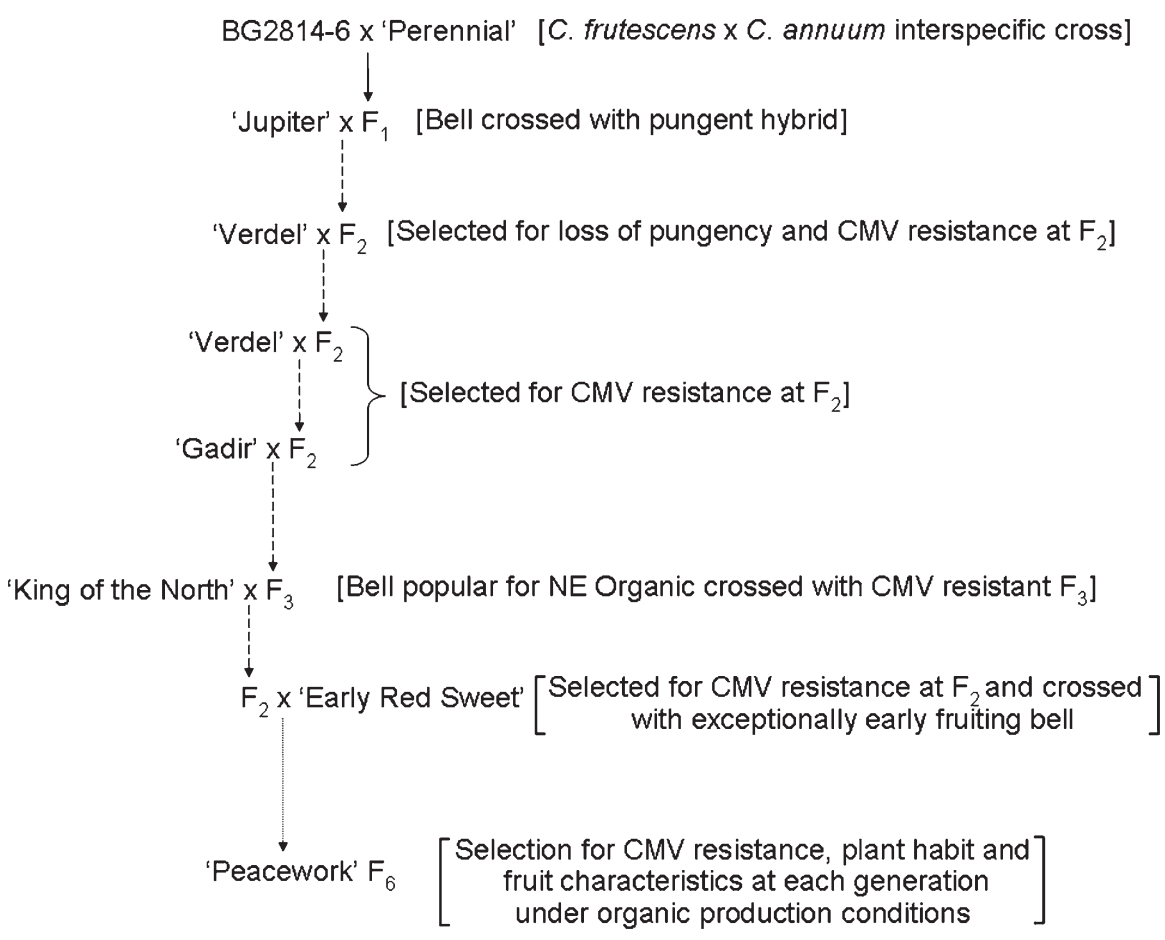

Fig. 1. Pedigree breeding and selection of 'Peacework'.

Partnership (http://www.plbr.cornell.edu/PSI/ OSP\%20home.htm). Selections were made for adaptation to their local conditions, disease resistance as well as quality and flavor as determined by growers and their customers. At the $F_{6}$ generation, the cultivar was named 'Peacework' and evaluated in replicated trials.

\section{Description}

'Peacework' ripens from green to red and was selected for earliness, yield, and pericarp thickness at the red-ripe stage (Fig. 2). During hot, dry conditions, it retains flowers resulting in consistent and sustained fruit set. 'Peacework' has a good stocky, upright habit and foliage cover that is sufficient for regions without intense solar radiation. Fruit are flavorful and sweet and Brix measurements routinely indicate $8 \%$ soluble solids. No absolute source of CMV resistance has been identified in pepper, but the multiple sources of resistance that are in the pedigree of 'Peacework' likely contribute to its high and consistent level of resistance (Greenleaf, 1986; Kang et al., 2005).

Comparative data. Replicated organic trials were conducted in 2006 at the Lewis Brown Horticulture Farm at Oregon State University and in 2007 at the Freeville Organic Research Farm at Cornell University in New York. At each location, seedlings were started in a greenhouse and received no sprays to manage insects or disease at any time. At the Oregon location, plants were transplanted to the field after 6 weeks and were $61 \mathrm{~cm}$ apart in single rows on a $76-\mathrm{cm}$ bed. Bio-grow 9-3-5 fish manure (BioBizz Worldwide, NV, Willemstad, Curacao) was banded in the row before planting at 618 $\mathrm{kg} \cdot \mathrm{ha}^{-1}$ and overhead irrigation was used. At the New York site, the peppers were transplanted after 7 weeks into double rows on plastic-covered $102-\mathrm{cm}$ beds spaced $2.1 \mathrm{~m}$ apart. Plant spacing within rows was $41 \mathrm{~cm}$. Before bed forming, dairy compost was spread at a rate of $19.6 \mathrm{t} \cdot \mathrm{ha}^{-1}$. Analysis of the compost indicated it was equivalent to $195 \mathrm{~kg} \cdot \mathrm{ha}^{-1}$ of nitrogen. At transplanting, each plant was watered in with a dilute fish emulsion. Three plots of 12 plants were grown at both locations and 10 plants from each plot were analyzed discarding data from the plants at the ends of the rows. Red-ripe fruit were harvested weekly after the appearance of the first red fruit and continued until frost.

'Peacework' was compared with two bell peppers from its pedigree that are also grown by regional organic growers, 'King of the North' and 'Early Red Sweet' (known for its high yields of small, thin fleshed fruit), and 'New Ace,' a hybrid bell pepper cultivar. In New York, 'Peacework' had significantly lower yield than 'New Ace' and 'Early Red Sweet' but was generally comparable to 'King of the North' (Table 1). With respect to fruit characteristics, 'Peacework' was found to be similar to 'King of the North' and 'New Ace' but was significantly larger than 'Early Red Sweet' (Table 2). In Oregon, however, 'Peacework' produced more but somewhat smaller fruit. 'Peacework' had significantly better yield than 'King of the North', was comparable to 'New Ace', and only lagged behind 'Early Red Sweet' with respect to fruit number. The fruit walls of 'Peacework' and 'King of the North' were consistently thick across environments. At both locations, 16 weeks after transplanting, 'Early Red Sweet' and 'New Ace' produced a greater number of fruit than 'King of the North' or 'Peacework' (Fig. 3). 'Peacework'
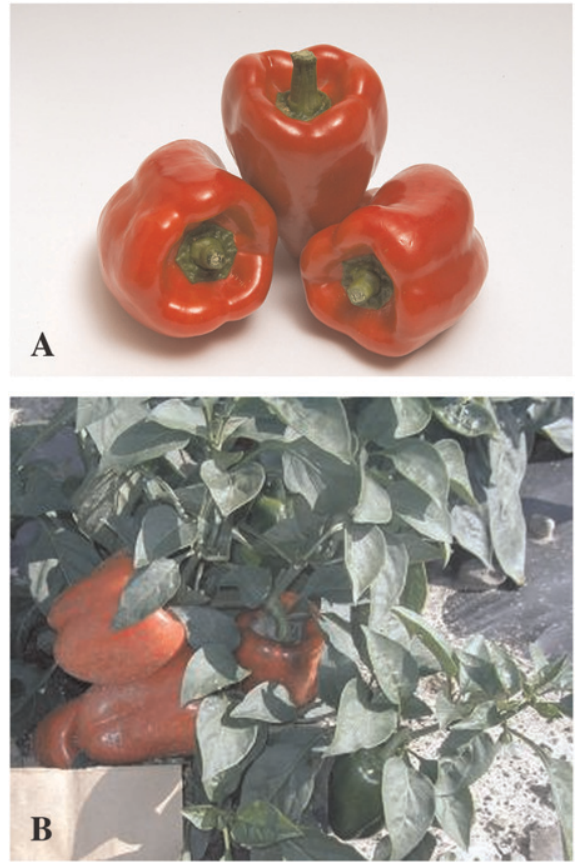

Fig. 2. Examples of ripe 'Peacework' fruit (A) and a plant in the field in New York (B).

produced equal numbers or more fruit than 'King of the North' and produced the second most fruit after 'Early Red Sweet' in Oregon. CMV symptoms were not noted on the susceptible plants in the trials suggesting an absence of natural infection. In a field where the CMV resistance of 'Peacework' could be distinguished, we would expect the marketable yield of 'Peacework' to exceed these susceptible varieties. Preliminary data indicate yields may be reduced in other geographical regions or under conventional production systems. 'Peacework' was selected for organic production in the northeastern and northwestern United States and our results indicate that 'Peacework' is well adapted to these conditions.

'Peacework' was selected based on a lack of symptoms after inoculation with CMVV27. Given that one parent in the pedigree was tolerant to CMV (virus accumulation with mild or no symptom), it was necessary to evaluate symptom development and CMVV27 accumulation in leaf tissues of 'Peacework'. Plants were inoculated as described, scored for symptom development, and tested for CMV-V27 accumulation in noninoculated leaves (systemic infection) at 3 weeks postinoculation using a commercial enzymelinked immunosorbent assay (ELISA) kit specific to CMV (Agdia, Inc., Elkhart, IN). ELISA procedures were as recommended by the kit manufacturer. After adding substrate, reactions were allowed to develop at room temperature for $\approx 30 \mathrm{~min}$ and then recorded using a BioTek $\mu$ quant plate reader (BioTek Instruments, Inc., Winooski, VT). A sample was considered positive for presence of virus if the ELISA absorbance value was greater than the healthy control threshold, which included three noninoculated plants of each 
Table 1. Organic early red bell pepper performance as a function of yield in New York (2007) and Oregon (2006).

\begin{tabular}{|c|c|c|c|c|c|c|c|c|}
\hline Cultivar $^{2}$ & \multicolumn{2}{|c|}{$\begin{array}{l}\text { Total number of } \\
\text { fruit (no./plant) }\end{array}$} & \multicolumn{2}{|c|}{$\begin{array}{l}\text { Number of marketable } \\
\text { fruit (no./plant) }\end{array}$} & \multicolumn{2}{|c|}{ Total yield (kg/plant) } & \multicolumn{2}{|c|}{ Marketable yield (kg/plant) } \\
\hline New Ace & $8.2 \pm 1.6 b^{y}$ & $7.5 \pm 0.9 \mathrm{bc}$ & $6.9 \pm 1.3 \mathrm{~b}$ & $6.1 \pm 1.4 \mathrm{bc}$ & $1.14 \pm 0.31 \mathrm{a}$ & $0.76 \pm 0.14 \mathrm{~b}$ & $0.99 \pm 0.26 \mathrm{a}$ & $0.62 \pm 0.17 \mathrm{~b}$ \\
\hline Early Red Sweet & $10.6 \pm 1.3 \mathrm{a}$ & $15.0 \pm 1.3 \mathrm{a}$ & $10.0 \pm 1.4 \mathrm{a}$ & $13.2 \pm 0.6 \mathrm{a}$ & $0.85 \pm 0.12 b$ & $1.06 \pm 0.05 \mathrm{ab}$ & $0.81 \pm 0.13 \mathrm{ab}$ & $0.93 \pm 0.00 \mathrm{ab}$ \\
\hline Peacework & $4.0 \pm 0.6 \mathrm{c}$ & $10.7 \pm 3.3 \mathrm{~b}$ & $3.6 \pm 0.6 \mathrm{c}$ & $9.1 \pm 2.8 \mathrm{~b}$ & $0.65 \pm 0.14 b$ & $1.29 \pm 0.41 \mathrm{a}$ & $0.59 \pm 0.09 \mathrm{c}$ & $1.09 \pm 0.34 \mathrm{a}$ \\
\hline $\begin{array}{l}\text { Least significant } \\
\text { difference }\end{array}$ & 1.7 & 3.7 & 1.5 & 3.2 & 0.27 & 0.47 & 0.22 & 0.40 \\
\hline
\end{tabular}

${ }^{\mathrm{z}}$ Varieties sorted in descending order based on New York total yield.

${ }^{y}$ Means followed by standard deviation and the same letters within columns are not significantly different based on Fisher's protected least significant difference $(P \leq 0.05)$ and were determined using SAS ${ }$ software (Version 9.1.3; SAS Institute, Cary, NC).

Table 2. Organic early red bell pepper performance as determined by fruit size in New York (2007) and Oregon (2006).

\begin{tabular}{|c|c|c|c|c|c|c|c|c|c|c|}
\hline \multirow[b]{2}{*}{ Cultivar $^{2}$} & \multicolumn{2}{|c|}{ Fruit wt $(\mathrm{g})$} & \multicolumn{2}{|c|}{ Fruit length $(\mathrm{cm})$} & \multicolumn{2}{|c|}{ Fruit width $(\mathrm{cm})$} & \multicolumn{2}{|c|}{ Length $\times$ width } & \multicolumn{2}{|c|}{ Fruit thickness $(\mathrm{mm})^{\mathrm{x}}$} \\
\hline & New York & Oregon & New York & Oregon & New York & Oregon & New York & Oregon & New York & Oregon \\
\hline New Ace & $137 \pm 11 \mathrm{~b}$ & $101 \pm 9 b$ & $9.2 \pm 0.3 \mathrm{a}$ & $9.8 \pm 0.2 \mathrm{a}$ & $7.8 \pm 0.2 \mathrm{a}$ & $5.9 \pm 0.2 b$ & $71.7 \pm 3.6 \mathrm{a}$ & $57.8 \pm 2.8 b$ & $4.0 \pm 0.0 \mathrm{ab}$ & $4.8 \pm 0.2 b$ \\
\hline Early Red Sweet & $80 \pm 3 c$ & $71 \pm 3 c$ & $7.0 \pm 0.2 \mathrm{c}$ & $8.0 \pm 0.3 b$ & $6.9 \pm 0.1 \mathrm{~b}$ & $5.8 \pm 0.1 \mathrm{~b}$ & $48.6 \pm 1.5 b$ & $46.0 \pm 2.5 \mathrm{c}$ & $3.0 \pm 0.0 \mathrm{~b}$ & $4.1 \pm 0.5 \mathrm{~b}$ \\
\hline $\begin{array}{l}\text { Least significant } \\
\text { difference }\end{array}$ & 22 & 24 & 0.7 & 0.9 & 0.5 & 0.7 & 8.1 & 10.9 & 1.5 & 1.6 \\
\hline
\end{tabular}

${ }^{\mathrm{z}}$ Varieties are sorted in descending order based on length $\times$ width for New York trials.

${ }^{y}$ Means followed by standard deviation and the same letters within columns are not significantly different based on Fisher's protected least significant difference $(P \leq 0.05)$ and were determined using SAS ${ }^{\circledR}$ software (Version 9.1.3; SAS Institute, Cary, NC).

${ }^{x}$ Fruit thickness is in terms of flesh, fruit wall, or pericarp thickness.

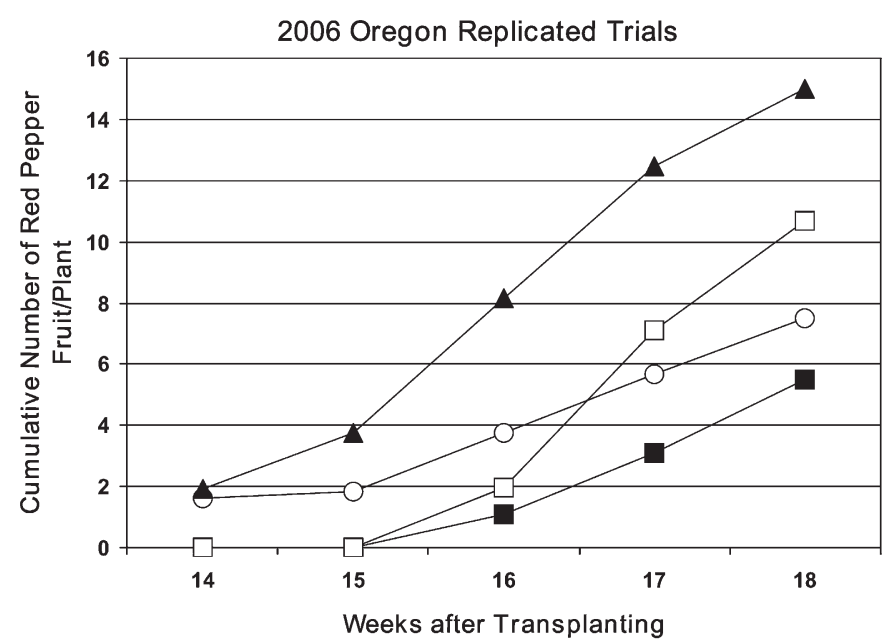

King of the North

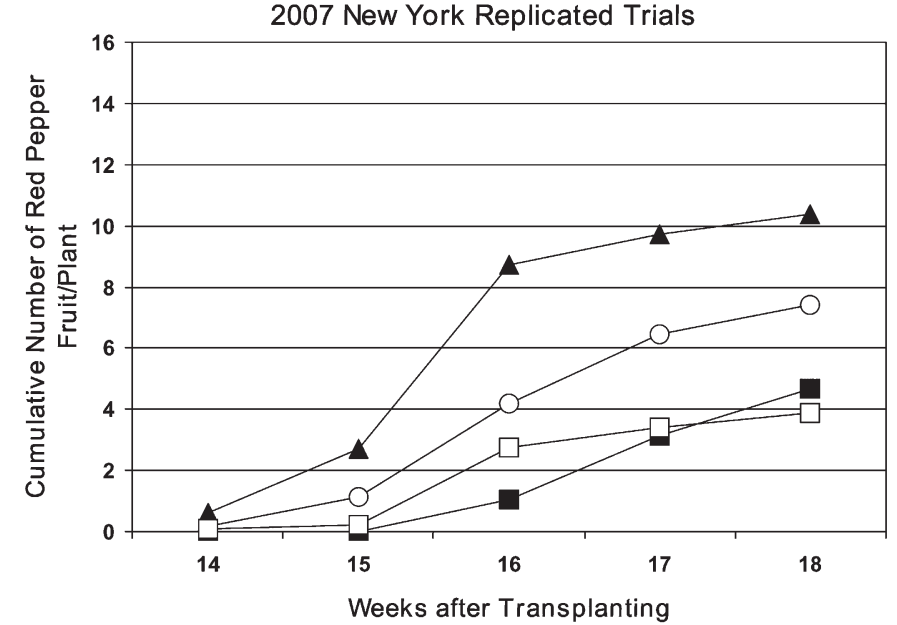

$-\mathrm{O}-$ New Ace
Peacework

Fig. 3. 'Peacework' yield through time measured by numbers of ripe fruit harvested during replicated trials in comparison with other varieties.

Table 3. Number of individuals of each genotype that accumulate different levels of Cucumber mosaic virus.

\begin{tabular}{|c|c|c|c|c|}
\hline Cultivar & No detectable virus ${ }^{z}$ & Low virus titer ${ }^{y}$ & High virus titer ${ }^{x}$ & Percent resistant \\
\hline$\overline{\text { BG2814-6 }}$ & $58(0)^{\mathrm{w}}$ & $2(0)$ & $0(0)$ & $97 \%$ \\
\hline Perennial & $56(0)$ & $2(1)$ & $0(0)$ & $97 \%$ \\
\hline Peacework & $120(0)$ & $9(5)$ & $9(9)$ & $87 \%$ \\
\hline King of the North & $15(0)$ & $21(17)$ & $37(37)$ & $21 \%$ \\
\hline New Ace & $28(0)$ & $11(10)$ & $62(62)$ & $28 \%$ \\
\hline
\end{tabular}

${ }^{2}$ ELISA value less than the average of the respective mock inoculated control plus 3 SDs.

${ }^{\mathrm{y} E L I S A}$ value between these two categories.

${ }^{x}$ ELISA value greater than three times the respective mock-inoculated control.

"Numbers shown in parentheses represent the number of symptomatic individuals in each category.

ELISA = enzyme-linked immunosorbent assay.

genotype. The positive category was further divided into groups that were greater or less than three times the average mock-inoculated value. 'Peacework's' response to inoculation

with CMV-V27 was compared with that of 'King of the North' (susceptible), BG2814-6, and 'Perennial' (both shown to be resistant; Grube et al., 2000).
CMV resistance in 'Peacework' is much improved over 'King of the North' (Table 3). BG2814-6 and 'Perennial' are two of the sources of resistance in the 'Peacework' pedigree. All BG2814-6 plants were asymptomatic, although two of the 60 plants had low but detectable CMV-V27 in noninoculated leaves. Similarly, CMV-V27 was detected in two of 60 'Perennial' plants with one of the infected plants expressing mild mosaic symptoms. Eighty-seven percent of 'Peacework' individuals were categorized as resistant to $\mathrm{CMV}-\mathrm{V} 27$ (i.e., plants were symptomless and CMV-V27 was not detected in leaves by ELISA). Among those 'Peacework' plants infected with CMV-V27, only those plants with high virus titer were severely symptomatic. In some cases, plants 
were symptomless but contained a low titer of CMV-V27 in noninoculated leaves (Table $3)$. Both 'King of the North' and 'New Ace' had far fewer resistant individuals, $21 \%$ and $28 \%$, respectively, and susceptible plants tended to be highly symptomatic and accumulate higher amounts of virus (Table 3.) 'King of the North' plants with low virus titer were highly symptomatic, which was not observed in 'Peacework'. This results from developing symptom phases in CMVinfected pepper plants in which later stages of infection continue to express symptoms but leaves contain significantly less virus (Murphy and Bowen, 2006). In summary, the CMV resistance in 'Peacework' is clearly higher than 'King of the North' and 'New Ace'.

\section{Availability}

Certified organic seed of 'Peacework' is currently available from Fedco Seeds, P.O.
Box 520, Waterville, ME 04903; (207) 8737333; http://www.fedcoseeds.com.

\section{Literature Cited}

Ben Chaim, A., R.C. Grube, M. Lapidot, M. Jahn, and I. Paran. 2001. Identification of quantitative trait loci associated with resistance to cucumber mosaic virus in Capsicum annuum. Theor. Appl. Genet. 102:1213-1220.

Greenleaf, W.H. 1986. Pepper breeding, p. 67-134. In: Bassett, M.J. (ed.). Breeding vegetable crops. AVI Pub. Co., Westport, CT.

Grube, R.C. 1999. Genetics of virus resistance in Capsicum and comparative analysis of disease resistance in the Solanaceae. PhD Thesis, Cornell University, Ithaca, NY.

Grube, R.C., Y.P. Zhang, J.F. Murphy, F. LoaizaFigueroa, V.K. Lackney, R. Provvidenti, and M.K. Jahn. 2000. New source of resistance to Cucumber mosaic virus in Capsicum frutescens. Plant Dis. 84:885-891.

Guerini, M.N. and J.F. Murphy. 1999. Resistance of Capsicum annuum 'Avelar' to pepper mottle potyvirus and alleviation of this resistance by co-infection with cucumber mosaic cucumovirus are associated with virus movement. J. Gen. Virol. 80:2785-2792.

Kang, B.C., I. Yeam, and M.M. Jahn. 2005. Genetics of plant virus resistance. Annu. Rev. Phytopathol. 43:581-621.

Murphy, J.F. and K.L. Bowen. 2006. Synergistic disease in pepper caused by the mixed infection of Cucumber mosaic virus and Pepper mottle virus. Phytopathology 96:240-247.

Murphy, J.F. and M.M. Kyle. 1995. Alleviation of restricted systemic spread of pepper mottle potyvirus in Capsicum annuum cv 'Avelar' by coinfection with a cucumovirus. Phytopathology 85:561-566.

Palukaitis, P. and F. Garcia-Arenal. 2003. Cucumoviruses. Adv. Virus Res. 62:241-323.

Stewart, C., Jr., B.-C. Kang, K. Liu, S.L. Moore, E.Y. Yoo, B.-D. Kim, I. Paran, M. Mazourek, and M.M. Jahn. 2005. The Punl gene for pungency in pepper encodes a putative acyltransferase. Plant J. 42:675-688.

Thorup, T.A. 2000. Genetics of fruit quality and resistance to cucumber mosaic virus in Capsicum. $\mathrm{PhD}$ Thesis, Cornell University, Ithaca, NY. 